\title{
Nuevos datos sobre la sociedad y el derecho celtibéricos: la regulación de la cabaña ganadera
}

\author{
Francisco Javier FERNÁNDEZ NIETO \\ Universidad de Valencia \\ fco.javier.fernandez@uv.es
}

\begin{abstract}
RESUMEN
Basándose en varios documentos medievales, mediante los cuales los reyes de la Corona de Aragón restablecieron un tribunal especial consuetudinario (tribunal del ligallo) para devolver a sus dueños el ganado mostrenco, el Autor determina el origen de este tribunal como antiquísima institución celtibérica y reconstruye su funcionamiento y papel en las sociedades célticas de la Península Ibérica. Esta corte de justicia, propia de todas las agrupaciones celtibéricas de siete miembros (oppida), se reunía dos veces por año, coincidiendo sus sesiones con las dos grandes festividades de Beltene (1 de mayo) y de Samain (1 de noviembre), y tenía como misión resolver todos los conflictos pecuarios surgidos en el seno de cada comunidad étnica. El nombre de ligallo no es sino la adaptación latino/románica de la voz Samain/ Samuhin.
\end{abstract}

Palabras clave: Península Ibérica, Celtíberos, tribunales ganaderos, federaciones celtibéricas de siete miembros, grandes fiestas célticas (Beltene, Samain).

\section{New information about Celtiberian society and rights: livestock law}

\begin{abstract}
Basing himself on various medieval documents by means of which the monarchs of the Crown of Aragon reinstituted a special common law court (the tribunal del ligallo) in order for stray cattle to be returned to their owners, the author traces the origin of this court to an extremely ancient Celtiberian institution and reconstructs its functioning and role in the Celtiberian societies of the Iberian Peninsula. This court of justice, typical of all the seven-member clusters (oppida) of the Celtiberian world, met twice a year, its sessions coinciding with the two major festivals of Beltene (1 May) and Samain (1 November), and its mission was to resolve all the livestock disputes that arose within each ethnic community. The name ligallo is a Latin/Roman loan translation of the word Samain/Samuhin.
\end{abstract}

Key words: Iberian Peninsula, Celtiberians, cattle farmers' courts, seven-member Celtiberian federations, major Celtic festivals (Beltene, Samain).

Porque el derecho, la realidad "derecho" - no las ideas de él del filósofo, jurista o demagogo- es, si se me tolera la expresión barroca, secreción espontánea de la sociedad, y no puede ser otra cosa.

(J. Ortega y Gasset)

Gerión

2011, vol. 29, núm. 1, 37-58 
En los últimos años he dedicado algunos trabajos a la reconstrucción de las instituciones y estructuras del mundo celtibérico, basándome en el enjundioso substrato de documentos y tradiciones más o menos vivas que han perpetuado hasta nuestros días las dimensiones religiosas, legales y políticas de aquella sociedad y que nos permiten rastrear sus remotos orígenes céltico-indoeuropeos. Entre los aspectos más instructivos anejos a tales investigaciones se halla, sin duda, la posibilidad de desvelar una serie de elementos directos e inmediatos del antiguo ordenamiento jurídico celtibérico -así como la forma en que éste era aplicado-, abriendo útiles e inesperadas perspectivas para comprender el conjunto social de los celtíberos. En esta contribución me propongo ofrecer nuevos materiales, tendentes a precisar el cuerpo normativo que rigió el derecho civil y penal celtibérico; en el presente caso, las normas que estudiamos poseen relación directa con la riqueza primaria de los pueblos de la Celtiberia, la ganadería. Para ello partiré de un venero de información que ha quedado recogido, afortunadamente, en fuentes medievales, aunque solamente cabe interpretarlo y encajar su verdadero origen teniendo en cuenta mis andamiajes previos.

Como marco de referencia debo recordar, aun sucintamente, el sistema oficial en torno al que giraban las grandes celebraciones religiosas celtibéricas peninsulares, que actuaron simultáneamente como asambleas políticas y foros judiciales, según he defendido con pruebas razonadas en anteriores artículos. ${ }^{1}$ Dentro de aquel bastidor hay que insertar estas nuevas proyecciones, puesto que de esa manera es como pueden rendir un conocimiento más completo no sólo del ámbito "federal" de los distintos grupos étnicos, sino en particular de la vida y usos de la sociedad celtibérica y de su uniformidad, ayudándonos a comprender tramas complejas que son propias de las entidades célticas y que en sus formas originales no hacen su aparición en otros lugares ${ }^{2}$, sino tan sólo en la Península Ibérica.

\section{El expediente medieval sobre el denominado ligallo (ligayo) o lligallo (lligalló)}

En virtud de un documento del rey Jaime I expedido en 1271 conservamos cumplida noticia de la existencia de una tradición ancestral en el territorio del reino de Valencia limítrofe con Aragón y Cataluña, tradición denominada ligallo, la cual fue reconocida por el monarca en los términos que luego expresaremos. ${ }^{3} \mathrm{La}$ importancia para noso-

1 F. J. Fernández Nieto, “La federación celtibérica de Santerón”, en F. Villar y F. Beltrán (eds.), Pueblos, Lenguas y Escrituras en la Hispania Prerromana. Actas del VII Coloquio sobre Lenguas y Culturas Paleohispánicas (Zaragoza, 12 a 15 de Marzo de 1997), Salamanca 1999, pp. 183-201; F. J. Fernández Nieto, "Religión, derecho y ordalía en el mundo celtibérico: la federación de San Pedro Manrique y el ritual de las Móndidas", en F. Beltrán, C. Jordán y J. Velaza (eds.), Acta Palaeohispanica IX. Actas del IX Coloquio sobre Lenguas y Culturas Paleohispánicas (Barcelona, 20-24 de octubre de 2004) [=PalHisp 5], Zaragoza 2005, pp. 585-618.

2 Tal como ha estudiado R. WildHABER, "Keltische Beiträge zur vergleichende Volkskunde", en H. Gerndt y G. R. Schroubek, Dona Ethnologica. Beiträge zur vergleichenden Volkskunde Leopold Kretzenbacher zum 60. Geburtstag, München 1973, pp. 11-27.

${ }_{3}$ El documento se halla publicado en la recopilación hecha por el notario L. Alanya a comienzos del XVI titulada Aureum opus regalium privilegiorum civitatis et regni Valentiae, Valencia 1515, fol. CCXXXIIIIv. (In extravagantibus, I). F. VAlLs TABerner, El tribunal del lligalló de Morella, Morella 1926 [opúsculo recogido en el libro A Fernando Valls i Taberner: 1888-1942, Barcelona 1964, 225- 
tros de este documento estriba en dos aspectos. Primero: porque abriga una concesión que no responde a un hecho novedoso o recientemente elaborado, sino a una vieja costumbre preexistente que sería ratificada por el monarca. Segundo: porque es la fuente más extensa y detallada para desentrañar los componentes del ligallo, instituto que podremos complementar con algunos otros miembros de varia procedencia (espacial y temporal) a los efectos de restaurar la originalidad primigenia de casi todo el procedimiento y de seguir sus huellas dentro de la antigua Celtiberia. En dicho privilegio de 1271, Jaime I autoriza a la ciudad de Morella y a sus aldeas a realizar (facere, celebrare) un ligallum regulado por los siguientes preceptos:

-La reunión o ligallo tendrá lugar dos veces cada año, debiendo coincidir la primera con el tercer día de Pentecostés (es decir, lunes de Pentecostés), y la segunda con el día de San Miguel (29 de septiembre).

-Ambas convocatorias se celebran con el objeto de congregar todo el ganado disperso considerado mostrenco (mezclado con otro, pero que no pertenece al mismo dueño) o que anda perdido (ganatum mostrench sive amissum).

-Es obligatorio que asistan al ligallo todos cuantos posean ganados (o los hayan tenido en el tiempo anterior a la convocatoria) paciendo en el término de Morella, o bien que los tales envíen a la reunión a sus pastores. Deben además llevar hasta el lugar de la congregación, cuando concurra dicha circunstancia, el ganado mostrenco que estuviese mezclado con el suyo propio. Quienes no asistan o no envíen a sus pastores serán castigados con una multa.

-Las reses mostrencas traídas al ligallo que encuentren propietario serán devueltas a sus dueños libremente y sin trabas (obviamente, cuando presenten pruebas objetivas de que les pertenecen).

-Si algún ganadero retiene animales mostrencos, pues no los trae al ligallo, y entonces quedase probada su responsabilidad, o bien posteriormente se le descubriese aquel ganado ajeno mezclado con el propio, tendrá que devolver el doble de cabezas a los dueños y pagará una multa al rey.

-Aquellos animales llevados al ligallo que no fuesen reclamados por nadie se tendrán de manifiesto y serán guardados hasta la siguiente reunión ${ }^{4}$. Si por segunda vez quedan sin adjudicar a una persona, pasarán a ser propiedad de la Corona.

-El baile y el concejo de Morella elegirán anualmente a un hombre idóneo para que, ante sí, impida las infracciones (distringat), recaude las sanciones pecuniarias (colligat) y haga observar cuanto el privilegio ordena (faciat observari); este juez único debe prestar juramento de que se guiará por la normativa recibida y urgirá su cumplimiento bene et fideliter.

232], pp. 5-7, editó una copia de este privilegio que fue realizada en el s. XIV y que se obtuvo no directamente del original de 1271, sino de un traslado del mismo efectuado en 1278. Pero debo señalar que esa copia de finales del XIV contiene algún grave error de lectura (quieti en lugar de convicti), que no fue advertido por Valls.

${ }^{4}$ Se entiende perfectamente que lo mismo sucede con aquellas reses que, habiendo sido vindicadas por su supuesto dueño, no queda probado que perteneciesen al reclamante, desestimándose por tanto la devolución. 
Todo este claro y escueto grupo de disposiciones de 1271 sobre el ligallo de Morella ${ }^{5}$ cabe precisarlo todavía más, a efectos de remontarnos al primitivo arquetipo, cruzando datos provenientes de otros dos reglamentos oficiales sobre la celebración de ligallos y su vertiente legal. Ambos fueron dictados en el s. XIV, aunque en ellos han sobrevivido interesantes elementos sobre la institución antigua. El primero de tales documentos reviste también la forma de una concesión o privilegio y se data en el año 1358. Fue otorgado por el maestre de la Orden de Montesa, Fray Pere de Thous, a los lugares de Canet, Rosell, La Barcella, La Jana y Cálig, permitiéndoles la celebración anual de dos ligallos, cuya finalidad era asimismo reunir y entregar a sus dueños los ganados extraviados, para evitar que pereciesen o que se perdieran irremediablemente. El privilegio consta de 16 parágrafos, que estipulan los diferentes requisitos de la convocatoria, las obligaciones y derechos de los propietarios de reses, el régimen de sanciones, las atribuciones de los concejos locales, así como las funciones y competencias del juez único o justicia del ligallo. ${ }^{6}$ Mas lo que del presente caso nos interesa son los siguientes extremos en particular:

-El privilegio se concede a cinco lugares, pero esta nómina nos sirve para seguirle el rastro a una antigua agrupación más amplia, compuesta por siete miembros, cuya existencia cabe históricamente conjeturar. La agrupación estuvo probablemente formada por las localidades de San Mateo, Traiguera, Cálig, La Jana, Canet, Rosell y Chert. ${ }^{7}$

${ }_{5}$ El ligallo ya existía en 1232, cuando la ciudad de Morella fue conquistada. Lo que hace el rey ahora es establecer oficialmente su legalidad, reconociendo la base del procedimiento y la competencia del tribunal ideado (juez único).

${ }^{6}$ AHN, lib. 542 C [Montesa], fol. 56-58; publicado por M. Gual i CAMARena, "L'institució ramadera del lligallo: unes ordenances desconegudes del segle XIV”, Estudis d'Historia Medieval 2, 1970, pp. 71-84 (el documento en pp. 82-84).

7 Es decir, por los antiguos focos de población sobre los cuales se asentaron las villas o lugares citados (como sucedió en los casos de las antiguas federaciones de siete miembros de Santerón, Atienza y S. Pedro Manrique, y que próximamente ampliaré con otros dos modelos también arquetípicos; vid. Fernández Nieto, trabajos citados en n. 1). Baso esta mi hipótesis en un documento del siglo XVI, el Libre dels Establiments de la vila de Chert (1689), donde figura la ley u ordenanza que debe regir en la denominada dehesa de Turmell, cuya área se delimita al final del texto. Allí se recoge que solamente las villas de San Mateo, Traiguera, Cálig, La Jana, Canet, Rosell y Chert (a las que el documento titula desde entonces la dita setena) puedan apacentar ganado menor y mayor en aquella dehesa. Si en el recinto penetrase cualquier extraño, como venían haciendo "los de Morella, Ballibona e altres cincunveïns", se les impondrá una pena de 7 bestias de día y 14 de noche ( $c f$. FERNÁNDEZ NieTo, Religión, derecho..., 600, n. 31: "la cuantía de las compensaciones establecidas en el derecho penal irlandés, que debe remontar al sistema jurídico céltico, parece haberse calculado en función de la división comunitaria en siete: 7, 21, 28 esclavas; 21, 35, 63, 84, 105 animales"). Anualmente serán elegidos dos hombres de cada lugar (14 hombres) con la misión de vigilar que se cumpla lo acordado, reseñar las infracciones y notificarlas a la superioridad (que es el lugarteniente del maestre de Montesa o el baile de cada universidad de la dicha septena). La ordenanza finaliza determinando el espacio que ocupa la dehesa: "La dita devessa de Turmell afronte, a una part, de Morella y ab terme de Ballibona, y ab lo riu de Servol, axí com devidix lo terme de Ballibona y de Servera, e devalla tota ribera del riu de Servol fins al riu de la Barcella y va per lo riu de la Barcella amunt fins a la Roca Foradada, e de la Roca Foradada va fins al camí de Rosell fins al riu Sec prop de San Mateo que per a avuy se diu la Rambla, y tot riu Sec amunt fins al terme de Morella" [el documento se halla en la colección titulada Establiments municipals del Maestrat, els Ports de Morella i Llucena (segles XIV-XVIII), Valencia 2006, 511 s.]. De todo ello podríamos deducir: 1. Que 
-Las dos fechas previstas para la concentración de los ganados o ligallos son el lunes inmediatamente siguiente a la Pascua de Resurrección, y la fiesta de los santos Simón y Judas del mes de octubre (día 28 de octubre).

-La devolución de las reses que un propietario reclame como propias se llevará a efecto si, mediante un juramento y otra prueba válida en derecho, se confirma que son suyas [\$9: provant amb son sagrament e per altra legittima prova que sien sues].

-A la persona elegida para juzgar como autoridad única los posibles incidentes, llamado el "justicia del ligallo", se le señala, entre otras funciones, la de dirigir la búsqueda del ganado sin dueño por los términos de los cinco lugares de su jurisdicción; en dicha tarea será auxiliado por los jurados de La Jana, y podrá conminar a traer dicho ganado a las reuniones convocadas.

El último testimonio que atañe a nuestro propósito es una carta del infante D. Pedro (futuro rey de Aragón, Pedro IV el Ceremonioso), hijo de Alfonso IV el Benigno, aprobada y confirmada en 1334. En ella atiende una petición de la sexma de Sarrión (Teruel) y ordena que los pastores del reino de Valencia que se beneficiaban de las hierbas del campo de Sarrión, pero no asistían a los ligallos, deben presentarse a tales juntas, cumpliendo todos sus requisitos y ordenanzas; deben también presentar, en caso de haberlos, los ganados sin amo conocido. No olvida luego determinar las penas aplicables a los contraventores de este mandato, autorizando a los alcaldes de los diferentes lugares para que ejecuten o levanten las sanciones previstas. ${ }^{8}$ Dicho texto adquiere tanta relevancia como los anteriores por tres razones, al menos:

-Porque las gentes de Sarrión basaron su petitus en la vigencia de un documento previo, sancionado por el rey Jaime I, en virtud del cual obligaba a todos los due-

la vieja federación constaba de los siete miembros canónicos, como cabía esperar, y que dicha armadura se mantuvo operativa y eficiente a afectos de preservar los derechos ancestrales sobre lo que era la sede religioso-político-económico-judicial del viejo grupo étnico, es decir, la dehesa de Turmell, centro de sus grandes fiestas y reuniones. Mas por alguna razón que se nos escapa, en lo relativo a la ordenanza del ligallo tan sólo cuatro de los antiguos miembros (Canet, Rosell, La Jana y Cálig) solicitan la concesión de este privilegio ganadero al maestre de Montesa, y a ellos se une un quinto lugar, La Barcella, que parece haber sido un caserío marginal del territorio antiguo (dentro de una dehesa de pequeño tamaño; en el documento de la setena aparece mencionado sólo para dar nombre a uno de los lindes, el río de La Barcella). ¿Fue tal vez porque San Mateo, Chert y Traiguera controlaban un importante mercado lanero, cuya salida eran los puertos de Vinaroz y Benicarló (GuAL, loc. cit., p. 79), y a efectos de jurisdicción no quisieron seguir implicados en aquel peculiar -y para ellos menos funcional- tribunal del ligallo? Es posible que el ligallo rindiera buenos servicios si existía una cabaña relativamente reducida, pero al sobrepasar los rebaños ciertas cifras o extender los aprovechamientos de pastos a otros territorios, a los miembros más activos les interesara desvincularse del mismo 2. La dehesa de Turmell tuvo que ser el lugar donde se celebraban las asambleas generales del grupo federativo, y en concreto las dos solemnes festividades anuales del calendario céltico (Beltaine, Samain; vid. infra): por consiguiente, allí estuvo asimismo la sede del aparato procesal (doble convocatoria) y del tribunal que, por influencia romana, se denominará ligaium o ligagium.

${ }^{8}$ Es el documento XXXI de la colección de M. de Bofarull y de Sartorio, Gremios y cofradías de la antigua Corona de Aragón (Colección de documentos inéditos del Archivo General de la Corona de Aragón, XL), Barcelona 1876, pp. 128-130. 
ños de rebaños a acudir al ligaium o legagium (de ambas formas se escribe en la carta) cuando se produjese la convocatoria del mismo. Habiendo facilitado copia de ese privilegio al infante D. Pedro (cuius transumptum nobis fuit exhibitum et ostentum), su cancillería lo reconoce como auténtico. Gracias a esta circunstancia, se nos hace patente que Jaime I también había otorgado otro privilegio similar o idéntico al de Morella para la comunidad de Teruel y sus aldeas. ${ }^{9}$

- Porque la carta emitida por el infante D. Pedro nos permite averiguar, acerca del invocado privilegio de Jaime I, que contenía "entre otras cosas, que todos los pastores están obligados a conducir personalmente o enviar a dicha congregación o ligallo, en la fecha en que se celebre, todo el ganado ajeno (ganatum extraneum), vulgarmente llamado mostrenco, que obre en su poder" ${ }^{10}$, y que una vez reconocido por sus dueños concedía a éstos el modo de recuperarlo.

-Porque en la exposición de motivos recogida en la carta, las gentes de Sarrión proporcionan un dato valiosísimo para encauzar retrospectivamente la historia del ligallo, a saber: que el documento por el que Jaime I reguló esta congregatio ganadera de Teruel y sus aldeas no obedecía a una iniciativa administrativa o acto de gobierno para delimitar un problema nuevo en el contexto socioeconómico, sino que se trató de un privilegium confirmacionis: después de comunicar a la corte que, desde tiempos muy remotos (a longinquis citra temporibus), los hombres que ahora formaban la villa y las aldeas de Teruel habían determinado (ordinatum) que los propietarios y pastores de ganado celebrasen una congregación anual llamada ligaio, solicitaron a Jaime I que las ordinationes sive statuta olim facta per dominos ganatorum, por las que desde otras épocas pasadas (olim facta) se regía aquella junta, fuesen confirmadas y ratificadas por el soberano, cosa que éste hizo.

\section{Los nexos entre el ligallo y el mundo celtibérico}

En el apartado anterior he recogido los datos estrictamente necesarios para ascender al origen y naturaleza de esta tradición ganadera. Tales datos constituyen el depósito esencial, por cuanto las demás informaciones sobre el desarrollo histórico de los distintos ligallos en época medieval y moderna ya no poseen interés ni relieve para el conocimiento del primitivo instituto, matriz de cuantos luego hubo. Precisamente, la forma en que esos otros ligallos evolucionaron y se extendieron pertenece al estudio de la sociedad medieval (moderna) y de sus regímenes políticos, una tarea que desborda con creces los límites de mi competencia y que recientemente ha sus-

9 En qué fecha fuese otorgado este privilegio del ligallo a la ciudad de Teruel no lo sabemos. Consta que en 1259 existía ya el ligallo de Teruel porque aparece incluido en la constitución orgánica de Teruel conocida como la Cerraja (GuAL, loc. cit., p. 81; J. A. FERnÁndez Otal, "La ganadería y la trashumancia en Aragón: una visión historiográfica", en J. L. Castán Esteban y C. Serrano Lacarra (eds.), La trashumancia en la España mediterránea. Historia, Antropología, Medio Natural, Desarrollo Rural, Zaragoza 2004, p. 68). Así pues, el reconocimiento regio estableciendo la legalidad de la institución puede datar de mediados del siglo XIII (más antiguo, por tanto, que el privilegio de Morella).

10 Resulta obvio, leyendo esta formulación, que el apelativo pastores utilizado en el documento constituye una mala redacción, pues lo correcto hubiera sido recurrir al concepto de "propietarios, dueños". 
citado la atención de experimentados cultivadores (infra, n. 47). Desde esta serie de datos primitivos, vamos ahora a destacar las piezas empleadas por los celtíberos para configurar el edificio jurídico que presidía la explotación del ganado, dejando para un último apartado el planteamiento de varios interrogantes, señalando asimismo las líneas y problemas abiertos por nuestra interpretación.

Habiendo examinado con detenimiento el anterior conjunto documental, caí de inmediato en la cuenta de que nos hallábamos ante una forma jurídica consuetudinaria de carácter oral, que nunca estuvo recogida por escrito antes de la Baja Edad Media y cuyos rasgos dominantes apuntaban inequívocamente a la civilización celtibérica. Son oportunas ahora las consideraciones de Hubert sobre el proceso de continuidad del sistema legal en la Europa céltica, puesto que los contenidos antiguos son anteriores a la redacción medieval: "Il en est de même pour les lois. Ni en Irlande, ni en Galles, ce ne sont des textes législatifs. Ce sont des coutumes. Or la coutume n'a rigoureusement pas de date en elle-même. La date est celle de l'état des sociétés auquel elles correspondent. C'est pourquoi il n'y a aucune raison pour ne pas servir des documents irlandais et gallois parce qu'ils ont été rédigés plus tardivement. Avec eux on peut reconstituer l'image de temps beaucoup plus anciens: il suffit de tenir notre sens critique en éveil à leur égard" (la cursiva es mía). ${ }^{11}$ Vale esto mismo para Hispania. Ocurre de nuevo que, gracias a la fidelidad asombrosa del comportamiento humano, un sistema pergeñado por una de las principales etnias prerromanas peninsulares para asegurar concordia y equidad internas discurrió intacto por los siglos de presencia romana, por la época de los visigodos y por la etapa de gobierno árabe. ${ }^{12}$ Algún estudioso de la ganadería hispana, como Klein, apuntó la posibilidad de que los ligallos presentaran antecedentes visigodos, remitiendo al hecho de que en el Fuero Juzgo (Lib. VIII, tit. IV, cap. XIV) se menciona la existencia de "asambleas locales para el reparto de los animales desmandados". ${ }^{13}$ Esta interpretación, sin embargo, no concuerda con dicho texto legislativo, ya que el capítulo en cuestión no registra ninguna clase de juntas o asambleas, ni menos aún de tribunales para dirimir derechos dominicales sobre el ganado errante, sino que solamente contempla un supuesto muy común en todo tiempo, cual es el de las reses que se mezclan con otro rebaño, y después se marchan, sin que haya incurrido en responsabilidad el dueño de este último. ${ }^{14}$

${ }^{11}$ H. Hubert, Les Celtes depuis l'époque de La Tène et la civilisation celtique ${ }^{2}$, Paris 1974, p. 203.

12 No sucedió así en todas partes, sino sólo en algunos territorios de la Península Ibérica donde hemos logrado rastrear la pervivencia de la cultura celtibérica; de tal manera que allí donde quedan todavía manifestaciones de las grandes festividades célticas, conservan más fuerza unos aspectos (élites, banquetes sacros, competiciones, ordalías) en detrimento de otros, que incluso se han borrado. Pero si tenemos la fortuna de encajar varias de estas piezas, el gran mosaico de la vida e instituciones en la Celtiberia se nos abre nuevamente con insospechadas perspectivas.

13 J. KLeIn, La Mesta 1273-1836. Estudio de la historia económica española, Madrid 1936, p. 23.

14 Fuero Juzgo XIV 4, 14: Antiqua. Si pecus alienum, sciente aut ignorante domino, gregi alterius misceatur. Si cuiuslibet pecora cum alicuius animalibus se miscuerint, et hoc ipse perspexerit, et sic de ipsius grege abierint, ut nullam ex hoc conscientiam habeat; dominus pecorum sacramenta ab eodem accipiat, quod non ipsius fraude vel culpa exinde abscesserint, et nec sibi ea praesumpsit, nec alicui tradidit, et nihil cogatur exsolvere. Quod si ad domum suam adduxerit, et iudicem non monuerit, vel in conventu publico infra octavam diem non contestaverit, duplum satisfaciat. Ley antigua. Si algun ganado (sabiendolo o ignorandolo el amo) se mezcla con alguna grey ajena. Si algun ganado se mezcla con otro ganado ajeno, e aquel cuya era la grey lo supiere, si despues se saliere no lo sabiendo el sennor

2011, vol. 29, núm. 1, 37-58 
Con mayor "aproximación conjetural" cabría haber exhibido los capítulos séptimo y octavo del mismo libro VIII, título V, del Fuero Juzgo, atribuidos a Recesvinto, donde se anotan los derechos y obligaciones de quienes guardan animales ajenos que encontraron extraviados, hasta que los recupere su legítimo amo. ${ }^{15}$ Todavía menor entidad posee, y me hago eco de la misma tan sólo a título de curiosidad, la sugerencia de Carreras sobre unos imaginarios orígenes musulmanes del ligallo, dado que ni siquiera se preocupa de ofrecernos alguna contribución testimonial en apoyo de esa filiación. ${ }^{16}$ Sin duda ambos investigadores llegaron a intuir que un estatuto tan rematado e insólito, restringido al principio a unos pocos territorios al sur del Ebro, no surgió de improviso como expresión de la vitalidad de los siglos XII-XIII, sino que allí latía la continuidad de una tradición más remota, llegada desde una época que vivió de cerca las duras realidades de la economía pecuaria, pero no encontraron el camino correcto. No, la verdadera pista no arranca del derecho romano tardío ni de la ley musulmana, sino que principia, como veremos, en el sedimento de la Celtiberia. Mas procedamos ya a recomponer aquella invención jurisdiccional que con posterioridad fue llamada ligallo.

1) Los dos ligallos anuales y su convocatoria. La primera clave para incardinar este primitivo modo de justicia en el mundo celtibérico son las dos fechas que, con algunos explicables desplazamientos, llegaron hasta la Edad Media. Pues resulta evidente que las dos reuniones anuales durante las cuales celebraba "vista" el "tribunal" ganadero no formaban un acto independiente y aislado, fijado sólo para sentenciar los incidentes detectados en el período anterior y reasignar la propiedad de las reses perdidas, sino que cada convocatoria -y la consiguiente actuación del tribunal- coincidía con una de las dos grandes festividades del calendario celta, el 1 de mayo (Beltaine)

de la grey, debe jurar al sennor del ganado, que non se salio por su culpa, nin por so enganno, e que él no lo ha, ni lo dio a otri, e sea quito. E si lo adujiere a casa con su ganado, e fasta ocho dias no lo dixiere en concejo paladinamente, péchelo en duplo.

15 Fuero Juzgo VIII 5, 7 : Antiqua. Ut errantia animalia occupata qui invenerit, diligenter habeas et conservet. Qui errantia animalia et sine custode invenerit, ita diligenter occupet, ut non evertat; sed sicut propia diligat atque custodiat. Quod si dominus qui perdidit caballum suum vel animal non eversum, sed dilectum et sanum invenerit, per singula capita maiora quaternas siliquas ille qui invenit accipiat, et quantum in substantia ipsius caballi vel animalis expendisse iuraverit, a domino caballi recipiat. Caeterum si everterit, duplum animal domino cogatur exsolvere. Ley antigua. Que aquel que falla animalia, que la deve guardar. Quien falla animalia ajena errada, e sin nenguna guarda, préndala de guisa cuemo la non danne; mas guárdela de guisa cuemo la su cosa. E si el sennor del caballo ó del animalia errada non la fallar dannada, por cada cabeza de ganado mayor dé al que la guardó la quarta parte dun sueldo, é quanto jurar el que la guardó, que despendió en el caballo ó en el animalia, todo lo peche el sennor. E si aquel que la tiene la fizo perdediza, peche dos tales animalias a so sennor. // VIII, 5, 8: Ne animalia errantia occupata aut tondeatur, aut caractere notentur, vel in alieno iure ducantur. Caballum captum errantem nullus tondere vel vendere praesumat. Caballis etiam aut bobus vel aliis quibuslibet pecoribus errantibus nulli liceat caracteres infigere. Quod si quis inventum animal vendere aut donare praesumpserit, secundum leges sicut fur teneatur. Qui vero totonderit, tres solidos compulsus exsolvat. Ita erit etiam ei, qui caracterem infixerit. Que aquel que falla la animalia errada non la deve sennalar nin tusar. Nengun omne que caballo errado tome o otra animalia, non la tuse, nin la tresquile, nin la venda, nil faga nenguna sennal. E si algun omne vende caballo errado o animalia, o la da, sea tenudo por ladron; e si la tusa o la tresquila, peche tres sueldos, e otro sí si la sennalar.

16 F. CARReras i CANDI, La navegación en el río Ebro. Notas históricas, Barcelona 1940, pp. 120 s. 
y el 1 de noviembre (Samain), lo que equivale a decir que la resolución de los conflictos generados por la explotación pecuaria del territorio era otro más de entre los ritos, actos judiciales y políticos, juegos y competiciones que durante los tres días que duraba cada una de estas dos panegyreis se sucedían.

Vimos anteriormente que, según el privilegio otorgado al grupo comunitario de Morella, la reunión o ligallo se realizará dos veces al año, debiendo coincidir la primera con el tercer día de Pentecostés (el lunes de Pentecostés), y la segunda con el día de San Miguel (29 de septiembre). A su vez, en el caso de los cinco lugares del Maestrazgo las dos fechas previstas para la concentración fueron el lunes inmediatamente siguiente a la Pascua de Resurrección, y la fiesta de los santos Simón y Judas del mes de octubre (día 28 de octubre). En el ámbito de la agrupación formada por Teruel y sus aldeas no ha quedado constancia de las fechas escogidas para concentrar a los ganaderos y a los animales mostrencos, ni tampoco lo sabemos en otros posibles pervivientes, como la federación de Ademuz y Castielfabib. ${ }^{17}$ Por fortuna, las dos informaciones conservadas son bien suficientes en función de su complementariedad. En efecto, las dos grandes festividades del calendario celta estaban asentadas cuarenta días después de los equinoccios, de modo que se desarrollaban respectivamente en torno al $1^{\circ}$ de mayo y al $1^{\circ}$ de noviembre.

Ya mostré en dos de mis anteriores trabajos cómo la antigua celebración del festival de Bel (inicio de mayo) se halla todavía latente en las provincias de Cuenca (territorio limítrofe con Ademuz/Teruel), Guadalajara y Soria, y su estudio me condujo a reconocer una organización federativa de los celtíberos formando un tronco de 7 miembros, los cuales actuaban como una asociación de tipo anfictiónico en torno a un santuario común, dentro del territorio propio, instalado en una dehesa. Es probable que cada una de estas federaciones contase también con un bosque sagrado, que habitualmente guardaba alguna relación con el santuario colectivo. ${ }^{18}$ Entonces explicamos cómo hasta los primeros siglos del cristianismo, la fiesta céltica de Beltaine (Beltene), o fiesta del «fuego de Bel», se organizaba a los 40 días del equinoccio de primavera (duración de un ciclo lunar y medio), es decir, el día 1 de mayo. Cuando el cristianismo ya estaba extendido por toda la Península Ibérica, en los territorios de substrato céltico la fuerza de esta tradición dominaba de tal modo que el ciclo de la Pascua no se clausuraba, como ordenaba la Iglesia, a los 50 días, sino a los 40, de

${ }^{17}$ No tengo más fundamento para presumir una antigua federación en torno a Ademuz que la noticia transmitida por GuAL (loc. cit., 81, n. 30) de que tiene documentados en la Edad Media unos "lligallos de l'enclavament valencià d'Ademús i Castielfabib". Nadie más los cita, pero es probable que Gual los encontrara documentados en el AHN, en donde extrajo el ligallo concedido por el maestre de Montesa, Pere de Thous, a los cinco lugares ya mencionados. En cualquier caso, no los publicó. Pero habida cuenta de que esa supuesta federación estaría contigua a la de Santerón (de la que formaba parte Vallanca, que pertenece al enclave de Ademuz), por un lado, y por otro a la de Teruel y sus aldeas, considero probable su existencia y, por supuesto, que contara con dehesa/santuario y tribunal del ganado. Más raro sería, pero no imposible, que Ademuz y Castielfabib conservaran un ligallo por haber pertenecido a la federación de Santerón (por haber estado englobadas ambas comunidades antiguas en el espacio de Vallanca).

${ }^{18}$ He tratado tales aspectos en dos trabajos: F. J. Fernández Nieto, "Leges templorum, leges luci y espacios sagrados en la Hispania romana", en L. Pons Pujol (ed.), Hispania et Gallia : dos provincias del Occidente romano (Colección Instrumenta, 38), Barcelona 2010, pp. $49-78$ (espec. 70 ss.); IDEM, "Encuesta sobre las regulaciones de los luci hispanos", Palaeohispanica 10 (2010), pp. 537-550. 
manera que la solemnidad final del tiempo pascual no era Pentecostés, sino la fecha en que luego fue hábilmente instituida la festividad de la Ascensión (40 días desde el domingo de Pascua; el problema afectó a numerosas iglesias, además de la hispana). Sólo entre los siglos IV y IX la jerarquía eclesiástica logró arrastrar esa celebración diez días después e hizo finalmente coincidir los ritos paganos con el Pentecostés cristiano. ${ }^{19}$

Pues bien, la primera junta del ligallo prevista en el estatuto de Morella guarda la coherencia histórica exacta con esa primera fecha esencial, propia de la secuencia anual celtibérica, que fue la fiesta de Beltaine, y es la misma fecha reservada para la fiesta que sobrevive en las tres federaciones citadas de Santerón, Atienza y S. Pedro Manrique (lunes de Pentecostés); mientras que en la segunda convocatoria se ha producido un adelanto respecto al triduum festivo de Samain, dado que se anticipa al día de S. Miguel (29 de septiembre). ${ }^{20} \mathrm{~A}$ su vez, en el caso de la antigua federación de S. Mateo/Chert la primera junta se encuentra notoriamente separada del momento original, puesto que se sitúa en el lunes inmediato posterior a la Pascua de Resurrección ${ }^{21}$; en cambio, la segunda ocasión del ligallo (la reunión de otoño) conserva con fidelidad la cita antigua, desde el momento en que la conmemoración de los santos Simón y Judas ( 28 de octubre) nos traslada muy bien al período de Samain, que empezaba con anterioridad al 1 de noviembre.

Afortunadamente, existe un tercer documento que contribuye a afianzar sólidamente esta tesis. El Llibre d'Establiments de la villa de Culla, que data de 1593, contiene una valiosísima ordenanza sobre el ligallo que debe remontar, como poco, al siglo XIV. ${ }^{22}$ Las disposiciones contenidas en esta ordenanza son iguales a aquellas que figuran en los restantes modelos (convocatorias, asistencia, reses mostrencas, justicia del ligallo, sanciones), pero lo verdaderamente notable son las fechas en que debe reunirse esta junta de ganaderos, para que sean entregadas y devueltas a sus dueños las reses mostrencas: el lunes de la Pascua de Pentecostés (que es precisamente el día

19 Fernández Nieto, Religión, derecho..., pp. $603 \mathrm{~s}$.

${ }^{20}$ Son tantos los factores que pudieron contribuir a adelantar este ligallo en concreto y llevarlo a la sanmiguelada, que carece de sentido consumir esfuerzo desarrollando conjeturas indemostrables. Es probable que a la Iglesia cupiese alguna responsabilidad en ello. Pero quizá influyeron simples motivos de oportunidad y conveniencia para adaptarse a la época (s. XIII, si es que el cambio no sobrevino ya durante la Antigüedad Tardía o durante el período de presencia musulmana). Tampoco debemos olvidar que el 29 de septiembre solían cancelarse los contratos de arrendamiento, y la comunidad de Morella podía tener arrendada una parte de sus pastos, por lo cual habría preferido anticipar la junta ganadera mudándola del 1 de noviembre al 29 de septiembre.

${ }_{21}$ Tal vez se produjo una confusión, a saber, que habiendo solicitado los cinco lugares celebrar el primer ligallo los lunes de la denominada Pascua de Pentecostés o Pascua Granada, fuera entendido por el dador del privilegio como los lunes de la Pascua tradicional. En todo caso, también cabría sospechar que en este territorio nunca se hubiese eliminado la serie de los 40 días desde el equinoccio primaveral, por lo que la Pascua de Resurrección quedaba numerosas veces mucho más cerca del 1 de mayo que el lunes de Pentecostés, en particular si el documento se estuviera refiriendo al lunes siguiente al lunes de Pascua (por considerar el redactor que la expresión Pascua de Resurrección era un conjunto cerrado que abarcaba domingo, lunes y martes de resurrección).

22 C. A. Rabassa i Vaquer, "Puntualizacions sobre la institució ramadera del lligallo. El lligallo de Culla", Millars. Espai i Historia 15, 1992, pp. 84 s. 
después de la elección del justicia), y el día de Todos Santos (1 de noviembre). ${ }^{23} \mathrm{Si}$ a ello añadimos que la comunidad de pueblos que formaban la denominada Tinença de Culla pudo ser la entidad sucesora, con bastante verosimilitud, de una antigua federación celtibérica de siete miembros (Culla, Benassal, Vistabella, Adzaneta, Benafigos, Torre d'En Bessora y Vilar de Canes), nos hallaríamos ante un segundo grupo federal celtibérico en el Alto Maestrazgo, confinante con los de San Mateo y Morella, grupo que, según toda verosimilitud, habría conservado inalterada la secuencia original propia de las dos fiestas célticas.

Que el cristianismo luchó con denuedo y varia fortuna para eliminar las seculares y poderosas construcciones del paganismo indígena no vamos a descubrirlo ahora, $\mathrm{y}$ en la pugna cooperaron a veces intereses puramente civiles (romanos, visigodos, árabes, de los reinos medievales), que perseguían afianzar el orden y promover la economía de ferias y mercados. Por consiguiente, resulta vano esperar que, al sucederse los siglos, los usos no hayan experimentado en algunos sitios cierto menoscabo y que las secuencias hayan perdurado inamovibles. Bastante rescoldo ha mantenido el vigoroso Geist celtibérico como para brindarnos todavía, aquí y allá, luces aisladas que logran orientarnos en esta percursatio obscura. Pero gracias a ambos informes documentales, puesto que cada uno ha protegido la mitad de la exactitud, alcanzamos a completar la solución global, confirmada además plenamente por el caso de Culla. Arribamos así a la primera premisa o eslabón de la trama: el ligallo premedieval parece haber sido parte integrante del contenido institucional de las federaciones celtibéricas de siete miembros, extremo que se evidencia no solamente a través de la estructura de las poblaciones que consiguieron, dentro de la Corona de Aragón, la restauración oficial de aquel tribunal (Teruel+aldeas; Morella+su grupo federal24; federación del Maestrazgo de Montesa; quizá el grupo ignoto de Ademuz; el grupo de Culla), sino también por la verosimilitud de que las dos audiencias primitivamente practicadas para que se impartiese la justicia "pecuaria" del ligallo se hallaban establecidas en los días de las fiestas de Beltaine y de Samain, es decir, en los dos soportes sobre los que pivotaba el año de celtas y celtíberos (1 de mayo, 1 de noviembre).

${ }^{23}$ RABASSA, loc. cit., pp. 86 s., que interpreta correctamente la expresión Pascua Granada como Pascua de Pentecostés. Conviene realizar aquí una relevante observación, y es que con el curso del tiempo en las ordenanzas de Culla se produjeron, como a menudo suele suceder, varios trastornos en las fechas, de modo que en cierto momento la primera convocatoria pasó al domingo de la Trinidad o domingo siguiente al de Pascua de Pentecostés, siguiendo un proceso que ya expliqué al estudiar las Móndidas (Fernández Nieto, Religión, derecho..., pp. 604 s.); mientras que en cierto momento se efectuó una tercera convocatoria del ligallo, a celebrar el 6 de agosto, día de San Salvador, bajo cuya advocación estaba la iglesia parroquial de Culla. Más tarde decidieron volver a convocar solamente dos ligallos, quedando situados en agosto (6) y noviembre (1), aunque tiempo después procedieron a la postrer reforma, reuniendo ligallo en Pentecostés y agosto (6). Este ejemplo resulta muy instructivo para percatarse de los numerosos trastornos que se producen y cuán prudente debe ser el análisis de las fechas adscritas a festividades cuando contamos solamente con escasos testimonios.

${ }^{24} \mathrm{La}$ antigua federación cabría seguramente reconstruirla a través del llamado Llibre del Pastoret o dels asagadors, que contiene los azagadores del ganado morellano distribuidos en siete circunscripciones: Castellfort, Portell, Olocau, Mata de Forcall, Forcall, Morella, La Tineusa o Tinausa: J. TuIXAns, "El tribunal del lligalló a Morella (segle XIII. Dret foral consuetudinari)", Boletín de la Real Academia de Buenas Letras de Barcelona 12, 1925-1926, pp. 175-177; Gual, loc. cit., p. 76. 
2) El lugar de celebración del ligallo. Según puede deducirse de los ejemplos conocidos, los actos que componían los festivales de Beltaine y Samain tenían como escenario el correspondiente santuario federal del grupo étnico. Eso significa que las distintas actividades habidas durante la panegyris se desarrollaban dentro del espacio propio del santuario, luego la junta de ganado o ligallo forzosamente debía ser congregada también en ese mismo lugar. En nuestros anteriores estudios comprobamos que estos santuarios indígenas habían ocupado dehesas especiales, en las cuales todavía hoy se conservan los ritos herederos del pasado celtibérico: la dehesa de Santerón, la dehesa de Atienza, la dehesa de S. Pedro Manrique. Veamos hasta qué punto esta condición se verifica asimismo en los casos que examinamos, pese a todas las inmutaciones padecidas.

El hecho de que en Morella la primera convocatoria del ligallo fuese el lunes de Pentecostés es indicio, ya lo dijimos, de que en aquella antigua federación una parte de la vida del santuario continuaba viva, aunque la Iglesia había logrado transferir lo que quedase de fiesta de los cuarenta a los cincuenta días después del equinoccio. Y este santuario no pudo ser otro sino la dehesa denominada de Vallibana (Vallivana) y Salvasoria. Existe constancia, efectivamente, de la gran importancia que esta dehesa revestía para aquella comunidad desde antes de que Jaime I diese carácter plenamente legal, mediante el privilegio de 1271, al tribunal del ligallo. ${ }^{25}$ Después de la conquista de la ciudad de Morella (1232), cuyo feudo fue concedido a D. Blasco de Alagón, el rey se reservó esta dehesa y la donó más tarde a su esposa Violante de Hungría; pero en 1241, ante el incremento experimentado por la población y la consiguiente expansión del ligallo, la reina Violante renunció a esa gran propiedad en favor de los morellanos, y aquéllos la destinaron, al parecer, para las necesidades del ligallo. Tiempo después, en el s. XIV, los ligallos comenzaron ya a convocarse por diversos lugares del territorio, razón por lo cual esta dehesa se destinó exclusivamente a pastos para el ganado mayor. ${ }^{26}$ Del mismo modo, la llamada dehesa de Turmell, a la que antes aludimos (supra, nota 7), sería el lugar donde se celebraba el ligallo de la federación del Maestrazgo hasta que, por razones ignotas, se produjo una desmembración de sus componentes (separación de S. Mateo, Traiguera y Chert), que era ya efectiva, al menos, en 1358. Luego cambió el escenario, pues las ordenanzas subsiguientes que los otros cuatro miembros (junto con el lugar de La Barcella) solicitaron al maestre de Montesa preceptúan que ambas reuniones arquetípicas (la de Pascua de Resurrección y la del 28 de octubre) se lleven a cabo en "lo dit loch de La Jana" $(\S 1)$. Sobre la dehesa federal de la comunidad de Teruel y sus restantes seis miembros no conservamos noticias. En definitiva, aunque los testimonios aplicables a las dehesas/santuario pertenecen a un momento en que la desintegración de los antiguos

25 Vid. Tuixans loc. cit., pp. 171 s., así como el Memorial (1762) citado por ValLs (pp. 13 s.) sobre el pleito que seguían varias villas y el Fiscal de su Majestad, coadyuvando su derecho, contra un vecino de Morella, en calidad de dueño de la Masía de Salvasoria, por suponerse ésta parte de la Dehesa de Vallivana.

26 Tuixans, loc. cit., pp. 171 s., que publica el documento, tomándolo de J. Segura y Barreda, Morella y sus aldeas. Geografia, Estadística, Historia, Tradiciones, Costumbres, Industria, Varones Ilustres etc. de esta antigua población y de las que fueron sus aldeas, I, Morella 1868, pp. 419 s. Pero ninguno indica en qué archivo se hallaba. Segura sólo refiere que la dehesa constituyó terreno de uso común para que sirviese de baldío (pastos); Tuixans mantiene expresamente que se destinó al ligallo. 
ritos y asambleas locales, que marcan la continuidad con las tradiciones prerromanas, estaba muy avanzada -y en tales santuarios, sitos dentro de tierras conquistadas por Aragón en el s. XIII, algunos usos ya se habrían extinguido- ${ }^{27}$, no obstante todavía cabe apreciar que las primitivas sedes de los sacros espacios federales eran percibidas y defendidas por la población del momento como porción esencial de los derechos colectivos y de la economía pecuaria.

3) Elementos integrantes de los festivales: la administración de justicia. Al reseñar la dimensión real de las caballadas de Santerón y de Atienza ya pusimos de relieve que, durante la celebración de la fiesta, una de las siete localidades del grupo federal -en cuyo territorio se encuentra el santuario común (dehesa)- ejercía la dirección de los actos. Estas reuniones poseían no sólo naturaleza religiosa, sino que funcionaban asimismo como verdaderas asambleas políticas anuales, un sistema que se halla igualmente certificado en otros dominios indoeuropeos. ${ }^{28} \mathrm{Y}$ es que los santuarios federales al aire libre actuaban simultáneamente como sede de las reuniones federales de las siete poblaciones celtibéricas que componían el grupo étnico; en tal momento se convocaba a su "consejo armado" para elegir un jefe militar, con la presencia y participación de los jefes de cada oppidum. La dehesa se convertía, además, en el escenario propio de las ceremonias religiosas y de los banquetes sacros, así como de juegos y competiciones de diferente índole.

Y existía, por añadidura, otra faceta que justificaba el aparato desplegado en cada ocasión. Me refiero a la administración de justicia en aquellos supuestos o esferas de intereses que desbordaban la tutela local e implicaban a varias partes del colectivo o a toda la etnia. El estudio de los componentes del rito de las Móndidas me llevó a una primera delimitación de tales prácticas, cuando analicé que aquella reunión anual daba soporte a una institución muy respetada en el mundo céltico, a saber, las llamadas ordalías o juicios de dios, cuya substanciación se aplazaba hasta la fecha de la fiesta (acumulando para entonces las causas graves o ciertas disputas legales que enfrentasen a particulares o a comunidades).

El hecho de que en las dos asambleas regulares anuales del grupo federativo se constituyese un tribunal de asuntos ganaderos cobra así mucho sentido, como veremos en el siguiente apartado, y nos permite ganar otro peldaño para comprender la energía que vigoriza el sistema legal celtibérico. Si las fechas de las reuniones y su ubicación en las dehesas (santuarios) ya apuntaban hacia los dos grandes festivales celtibéricos, es la propia condición del ligallo -instrumento procesal confiado a un tribunal especializado en entender de un objeto pecuario que involucra a todas las comunidades del grupo- lo que recomienda positivamente considerar que su sede "natural" estaba en el interior de ambos festivales, cuando también se ponía en marcha la justicia "ordálica" y, probablemente, se ejercían otras jurisdicciones (pena capital).

${ }^{27} \mathrm{Al}$ contrario de lo acontecido en Santerón, Atienza y S. Pedro Manrique (más otros dos casos que deseo publicar en breve), donde los ritos y buena parte de los elementos destacados de la fiesta han llegado hasta nuestros días con relativa nitidez.

${ }_{28}$ Estados federales griegos y anfictionías, que celebraban dos asambleas anuales (primavera y otoño). Entre los celtas, como recuerda Hubert (op. cit., p. 258), "ces fêtes étaient des foires, des assemblées politiques ou judiciaires et aussi des occasions de divertissements et de jeux dont quelques-uns, comme les courses, étaient d'origine religieuse". 
No debemos además perder de vista que la ordalía constituyó siempre un recurso legítimo y definitivo para zanjar cualquier batalla judicial, de modo que el tribunal ganadero podía ordenar su puesta en práctica, o ser solicitada por los implicados, cuando no les bastase el juramento u otro tipo de prueba. Y para contrastar mejor hasta qué punto conviene que esta nueva pieza del mosaico, que es el ligallo, tenga cabida entre las instituciones de los festivales celtibéricos, ayudándonos a recomponerlos, desarrollamos el siguiente apartado.

4) ¿Qué función cumplía realmente el cylch? La razón de ser del tribunal del ligallo que nos describe la documentación medieval estribaba en encontrar a los legítimos dueños las reses perdidas; sin embargo, para llevar esta misión a buen puerto se requería ante todo el protagonismo cooperante de los propietarios del ganado y de sus pastores, que previamente condujesen aquellas reses en las fechas precisas hasta el lugar designado. El correspondiente juez se limitaba entonces, y no era poco, a asignar los animales a quien los reclamaba, o bien a rechazar la pretensión; a dirimir el caso entre dos pleiteantes; a decidir la custodia, hasta la siguiente junta, de aquellos que continuasen sin dueño; finalmente, a declarar bien público las reses no adjudicadas en dos ligallos consecutivos. A nadie escapaba, pues, que el tribunal sería capaz de cumplir la tarea encomendada siempre que todos los propietarios acatasen el mandato legal e hiciesen llegar puntualmente el ganado mostrenco y extraviado; el problema serio y acuciante emergía cuando las previsiones fallaban y entonces el tribunal, bien de oficio bien por haber recibido una denuncia, debía localizar por sí mismo dónde pacían los mostrencos, sancionar a quienes dolosamente no los trajeron y devolverlos a quienes fuese procedente.

Que ahí radicaba el verdadero punto débil del ligallo se revela de inmediato en la concesión y privilegio otorgado en 1358 a los cinco lugares de la vieja federación del Maestrazgo. El texto ordena primero que las convocatorias coincidan con Pascua de Resurrección y el 28 de octubre $(\S 1)$; decreta luego que cada año los jurados y consejeros de La Jana elijan y creen a una persona del lugar como justicia del ligallo, la cual deberá jurar que ejercerá su oficio honesta y fielmente, y que impondrá con rectitud y diligencia las penas previstas en los diferentes apartados si se comete alguna infracción (§2). Acto seguido especifica: "Item, que el justicia de dicho ligallo y los jurados del dicho lugar (La Jana), conjuntamente y cualquiera de ellos en ausencia del otro o de los otros, puedan realizar búsqueda, por todos y cada uno de los lugares de la jurisdicción del dicho lugar (La Jana) y de los demás lugares arriba mencionados que en dicho lugar de La Jana están obligados a efectuar dicho ligallo, en la forma que ellos consideren más adecuada, de los ganados mostrencos, extraviados y "radivos", tanto de los foráneos como de los propios. Y cuando fuesen encontrados por ellos, que digan a los pastores y guardianes de los rebaños de ganado donde estén dichos animales mostrencos y "radivos", que los dejen llevar y lleven a dicho ligallo; y si no quisieran hacerlo, que entonces dichos jurados puedan decirlo y manifestarlo al dicho justicia de dicho ligallo; y que entonces dicho justicia del dicho ligallo pueda forzar y constreñir a los pastores o guardianes de dichos rebaños, entre los cuales se hallen 
dichos animales mostrencos y "radivos", a llevarlos al dicho ligallo" $(\S 3) .{ }^{29} \mathrm{Y}$ a partir de este parágrafo se suceden ya las consabidas normas sobre asistencia obligatoria al ligallo con las reses que sean ajenas, recuperación de las mismas, custodia de las que deben guardarse hasta la siguiente junta, sanciones e indemnizaciones, etc. De donde se deduce claramente que tan sólo ejerciendo el justicia y sus auxiliares esa continua vigilancia cabía garantizar la viabilidad del sistema y dificultar los fraudes, y que este empeño era tan firme que su ejecución se sitúa a la cabeza del corpus normativo.

Regresemos a la Celtiberia. En mi trabajo sobre la federación de San Pedro Manrique, al estudiar la parte de la celebración denominada la «descubierta» (recorrido circular a caballo de todo el recinto) supuse que podríamos estar en presencia de la institución del cylch, recogida en los Mabinogi y explicada por Loth como el viaje circular anual del rey o jefe de un distrito, acompañado de sus principales oficiales, con el fin de vigilar sus dominios y dejar constancia de su autoridad. Entendí entonces que aquella muestra ancestral del primitivo festival sería expresión "del viaje circular que los jefes de la federación debieron de efectuar por los contornos del distrito", y lo interpreté en dos sentidos: serviría para afianzar los límites y el dominio efectivo sobre el territorio, pero también como posible ceremonia ritual mágico/religiosa. Debo en buena medida rectificar, pues ahora distingo mejor el papel esencial que correspondía al recorrido circular o cylch, en el contexto concreto de la fiesta, gracias a esta nueva pieza del ligallo, que encaja perfectamente con cuanto habíamos entrevisto sobre los grandes festivales celtibéricos y su interacción como asamblea político-judicial.

Tratemos de situarnos en las circunstancias pretéritas de aquel mundo. La importancia del ganado en la sociedad celtibérica está suficientemente contrastada no sólo por numerosos restos arqueológicos (sin olvidar las téseras), sino también por la insistencia de los autores clásicos al considerar que el patrimonio pecuario constituía su principal fuente de riqueza. Como en el resto de los grupos célticos europeos, la riqueza esencial de las comunidades celtibéricas fue también una riqueza en ganado (bóvidos y caballos), que los individuos acomodados llevaban a pastar a las tierras comunales, de las cuales tendían a apropiarse. ${ }^{30}$ Rebaños y manadas pertenecientes a las principales familias de cada grupo étnico debían andar dispersos por el territorio propio, para aprovechar toda clase de pastos; el número de estas cabezas se vería a veces incrementado por algunos hatos procedentes del botín, fruto de operaciones y golpes por sorpresa contra comunidades vecinas, que no eran infrecuentes, e incluso

29 El parágrafo concluye determinando las sanciones pecuniarias que el justicia puede imponer contra quienes desoigan este mandato, castigo que podrá reiterar cuantas veces se cometa la infracción. La expresión radiu, radives, que contiene el original catalán y he transcrito como "radivos" podría derivar de la raíz latina del verbo radeo, radere, pues en catalán anar a raure significa ir por libre, ir a su aire (datos que agradezco al Prof. Dr. Albert Hauf). Serían, pues, animales que andan por su cuenta sin nadie que los vigile.

${ }^{30}$ Véase J. Costa, Estudios ibéricos, Madrid 1891-1895, pp. I-XXXVIII (Ganadería ibérica) y pp. XXXIX-LIV (Cuatrería o abigeato); IDEM, Colectivismo agrario en España. Partes I y II. Doctrinas y hechos (Obras completas, vol. V), Madrid 1915, §49; J. Gómez-PantoJA, "Pastores y trashumantes de Hispania", en Poblamiento celtibérico, II (III Simposio sobre los celtiberos), Zaragoza 1995, pp. 495 s.; para la Meseta, en líneas generales, J. R. Álvarez-SAnchís, Los señores del ganado. Arqueología de los pueblos prerromanos en el occidente de Iberia, Madrid 2003, pp. 53-55. 
por exacciones internas o por confiscación de patrimonio (por un delito social). De todo ello han quedado elocuentes testimonios en las composiciones épicas del tronco céltico en algunas literaturas europeas, así como en la literatura griega. ${ }^{31}$ Puede ser que los propietarios y cuidadores del ganado se guiasen por las señales externas naturales (pelaje, manchas, cornamenta, cola, etc.) para reconocer a los animales -pericia que todavía hoy poseen muchos pastores-, e incluso que ciertos animales y rastras (equinos y bovinos, padres) hubiesen recibido un nombre, aunque tampoco resulta improbable que estuvieran ya extendidas algunas formas de marcar las reses con señales tanto permanentes como temporales..$^{32}$ Pero eso no evitaría problemas, sobre todo si los rebaños quedaban sueltos y sin vigilancia la mayor parte del tiempo, pues necesariamente acabarían creándose confusiones; a ello debe sumarse que otras partidas de animales quedaban aisladas por el mal tiempo y la nieve, y podían ser diezmadas por las fieras. ${ }^{33}$ Tanto en el caso de los ganados lanares, como de los bovinos y equinos, si las pérdidas y extravíos alcanzaban relevancia económica es seguro que nacerían tensiones y que se correría el riesgo de abrir serias grietas en el grupo federal. En el interior de cada oppidum tuvo que ser habitual que los ganados dispusiesen de zonas comunes de apacentamiento, de modo que todo el colectivo conocería los rebaños propios; mas cuando las reses de cualquiera de las otras seis comunidades federadas se dispersaran por los territorios de dicho oppidum, o su mismo ganado pasase a espacios ajenos, las cosas se hacían más complejas, los contactos más tensos y los títulos de propiedad empezaban a palidecer. ${ }^{34}$

Cierto, en aquellas redes no era concebible la figura del juez único que, por encima de las jefaturas, sustanciase las distintas reclamaciones durante los seis meses que transcurrían entre ambas citas colectivas (Beltaine y Samain), ni el que se le dotase de jurisdicción permanente; tampoco el sistema de instituciones celtibéricas toleraba que fuera asistido únicamente por seis auxiliares. La acción social ejemplar de la justicia y del castigo tenían su momento y lugar en la fiesta, en presencia y con parti-

${ }^{31}$ Recordemos el famoso poema Tain Bó Cúalnge ("Correría en busca de ganado de Cooley”), que forma parte de la mitología celta de origen irlandés (Ciclo del Ulster), así como los relatos de las hazañas de algunos héroes y guerreros en torno al robo de ganado (B. Lincoln, Sacerdotes, guerreros y ganado. Un estudio sobre la ecología de las religiones, Madrid 1991, pp. 108-114; 144 ss.). Frontino menciona que los lusitanos solían robar el ganado de los segobricenses (Strat. III 10, 6); vid. Costa, Estudios ibéricos, pp. XXXIX-LIV. Para el caso griego, véase G. DotтIn, "Les razzias épiques", Revue Celtique 40, 1923, pp. 127-134.

32 Sobre la marca del ganado en el mundo antiguo véase P. PERDRIzet, "La miraculeuse histoire de Pandare et d'Echédore, suivie de recherches sur la marque dans l'Antiquité", Archiv für Religionswissenschaft 14, 1911, pp. 54-129; U. FANTASIA, "Astikton Chorion", Annali della Scuola Normale Superiore di Pisa, ser. III, vol. VI, 4, 1976, pp. 1165-1175; C. P. Jones, "Stigma: Tattooing and Branding in Graeco-Roman Antiquity", Journal of Roman Studies 77, 1987, pp. 139-155; S. GEORGOUd, Des chevaux et des boeufs dans le monde grec. Réalités et répresentations animalières à partir des livres XVI et XVII des Géoponiques, Paris-Atenas 1990, pp. 145 s.

${ }_{33}$ Por ejemplo, los animales procedentes de un mismo botín serían repartidos entre toda la comunidad, pero luego se mezclaban y resultaba complejo reconocer los que habían correspondido a cada familia. En otros lugares las reses permanecerían aisladas por la nieve, quedando a merced de alimañas o de grandes depredadores.

${ }^{34}$ ¿Había que pagar una indemnización por gastos, a quien los tuvo mezclados con los suyos, en el momento de venir a recogerlos? Problemas de esta naturaleza necesitaban ser resueltos por una instancia legal, con criterio uniforme. 
cipación de todo el colectivo federal, pues aquel problema ni era asunto que afectase sólo a los propietarios de ganado (mientras que en la Edad Media fue una jurisdicción y tribunal gestionado para y por los ganaderos), sino a los intereses vitales de la etnia como persona jurídica, ni el entramado de la soberanía religiosa (dioses: ordalía) y política consentía que se transfiriese a una persona cualquiera el ejercicio exclusivo de la administración de justicia. Los tres días del festival constituyeron, por tanto, la totalidad del plazo con que se contaba para establecer el tribunal y proceder a las reclamaciones y a las devoluciones; después, el foro queda cerrado hasta el siguiente festival. Ahora se entiende y justifica la forma operativa del ligallo. En el curso de Beltaine y Samain se intercalaba, según sabemos, un momento reservado para que se manifieste la justicia. Junto a la práctica de las ordalías, una vista o audiencia siempre fija debió de consistir en las reclamaciones o querellas respecto al ganado. Es muy probable que el derecho celtibérico contemplase ya la obligación de que quienes tuviesen reses mostrencas habían de traerlas a la fiesta convocada; pero al mismo tiempo, el propio tribunal se desplazaba a caballo por el área del territorio, siguiendo un recorrido circular variable que pasaría por los lugares de los siete oppida donde estaban los ganados, verificando si todo se hallaba en regla o alguien había retenido animales que no le pertenecían o estaban reclamados. ${ }^{35}$ Tal sería la función primordial del cylch, con el que los jefes dejaban asimismo constancia del beneficio de la autoridad, puesto que después del recorrido (y de emitir sus fallos) quedaría indiscutida y definitivamente adjudicada la fuente básica del patrimonio colectivo, el ganado.

A su regreso al lugar de la asamblea (dehesa), los miembros del cylch constituirían tribunal, siendo presididos por el jefe elegido anualmente en esa misma o en la anterior fiesta federal, como ya expliqué a propósito de Santerón y Atienza ${ }^{36}$; es muy verosímil que fuese el jefe quien pronunciara el fallo definitivo de cada caso, de suerte que éste fuese inapelable y aceptado por el conjunto de los siete oppida. Sobre los ilícitos penales, las reglas procesales y el tenor de las normas aplicadas por costumbre caben pocas conjeturas, que deben armonizar, mutatis mutandis, con lo que sabemos del posterior ligallo. Creo que el tribunal celtibérico del ganado asumía una primera función consistente en controlar las deudas de reses: sabemos, en efecto, que en Irlanda las familias más ricas prestaban una parte de su ganado, y que con sus deudores establecían una especie de clientela. El régimen de préstamos adoptaba dos tipos: el llamado ganado libre no entrañaba riesgo personal para el tomador, pues al vencimiento de la deuda respondía sólo con sus bienes, aunque la operación era bastante costosa. A su vez, el denominado "ganado siervo" era prestado en condiciones económicas más ventajosas, pero el tomador se exponía a un cambio de condición,

35 El recorrido era relativamente sencillo. En la federación de Santerón, por ejemplo, bastaba con visitar varios lugares muy aptos para el ganado (dehesillas y vallecillos): Santeroncillo, Tólmeda, Vallongo, La Cunázara, Vallanca. Sin duda, en virtud de informes previos los componentes del cylch sabían ya en qué lugares debían afinar la vigilancia.

36 Son los mismos jefes que participan en el banquete ritual (Santerón, Atienza, S. Pedro). El hecho de que en las antiguas ordenanzas del ligallo de Culla (que conservan con total exactitud las fechas primitivas de ambas festividades celtibéricas) se determine que el justicia será nombrado el día antes del lunes de Pentecostés, podría ser una reminiscencia de que la elección anual del jefe político y juez supremo tenía lugar el segundo día de Beltene. 
perdiendo su libertad si no reintegraba la deuda ${ }^{37}$ De existir algo similar entre los celtíberos, no cabe duda de que los problemas generados por tales préstamos traerían consecuencias constantes, cuya solución pasaría por este tribunal. ${ }^{38}$ Pero además, parece consecuente suponer que el tribunal -entiéndase el jefe federal, oídos los componentes del cylch, donde se hallan representadas todas las partes-asignaba de nuevo a los respectivos dueños las reses perdidas siempre que se probara que eran suyas; sospechamos también que se procedía esencialmente mediante solemne juramento (sacramentum), mas cuando éste era impugnado, bien se retiraba la pretensión del reclamante, bien se obtenía la prueba recurriendo a la clarividencia divina (ordalía) ${ }^{39}$. Resulta asimismo verosímil que el juez podía exigir que los propietarios que recuperaban sus animales compensaran a quienes cuidaron de los mostrencos, así como imponer sanciones a quienes no trajeron el ganado perdido o pretendieron ocultarlo (les obligaría a la devolución de los mostrencos y a la entrega, como multa, de otros animales $)^{40}$; por último, es lícito presumir que las reses no adjudicadas a nadie formarían un fondo común, siendo repartidas entre las siete comunidades (oppida) celtibéricas aplicando algún criterio proporcional. ${ }^{41} \mathrm{Si}$ esto fue así, cabría entonces decir que aquel sistema tan práctico y nada complejo, erigido como una jurisdicción complementaria y autónoma del derecho civil, demostró hasta tal punto su adaptación en múltiples territorios a las exigencias naturales del aprovechamiento ganadero, que logró pasar casi intacto de la Antigüedad al Medioevo, e incluso superó la prueba de la Edad Moderna. ${ }^{42}$

5) Los nombres de la fiesta y el nombre de ligallo. ¿Podría el nombre de ligallo poseer relación directa con el origen celtibérico de la institución? En su Tesoro de la lengua castellana o española había escrito Sebastián de Covarrubias que mesta es "cierta jurisdición que compete a los ganaderos; es dificultosa su etimología; diré lo que siento, remitiéndome a mejor parecer. Mesta se dijo quasi mixta, por la concurrencia de diversos hatos y manadas, y porque restituye las que se han mezclado con otras, las cuales son conocidas por los hierros o señales... Confirma esto el vocablo aragonés que a la mesta llama ligallo, que en castellano vale liga, y liga es junta, confederación y amistad".

Conviene que exploremos si hubo otra razón, más allá del aspecto puramente descriptivo, para adherir este apelativo a las operaciones realizadas por el tribunal.

37 Hubert, op. cit., p. 233.

${ }^{38}$ No es difícil imaginar que, con independencia de que se hubiese tomado en préstamo ganado libre o ganado siervo, los extravíos de reses ponían en dificultades a los deudores y favorecían, en cambio, al prestamista, por lo que algunas desapariciones "provocadas", las ocultaciones del ganado mezclado con el propio, el apropiarse y esconder ganado ajeno para hacer frente a la deuda, etc., podían ser frecuentes, enriqueciendo a unas familias en detrimento de otras. Tal vez la necesidad de poner orden en este tipo de actuaciones sería lo que dio origen al ligallo.

39 Fernández Nieto, Religión, derecho..., pp. 606-609.

${ }^{40}$ Recuérdese lo dicho sobre multas y sanciones, que son múltiplos de siete para poder entregar la misma porción a cada uno de los siete grupos.

${ }^{41}$ Esto debía ser la norma general cuando las reses procediesen de otra federación vecina.

${ }^{42}$ El tribunal del ligallo de Morella fue suprimido en 1835; sobre el resto de los ligallos y sus competencias hasta la Edad Moderna vid.infra, nota 47. 
Sabemos que el nombre Samain (Samuhin, Samonios en el calendario de Coligny) de la fiesta del 1 de noviembre se traducía en Irlanda como sam+fuin, es decir, fin del verano; pero esa equivalencia era incorrecta, pues en realidad samuhin significa "asamblea, concentración, reunión, junta". ${ }^{43}$ Además, la fiesta de Beltaine (Beltene) recibía un segundo nombre en antiguo irlandés, que no era otro sino el de cét-samain ("primer samain" o "samain opuesto"). Nada tan natural, como hace de Vries (infra, n. 45), que plantearse de inmediato esta pregunta respecto al significado del nombre de Samain: Mais que représente ce samuhin? De quelle "reunion" s'agit-il?

Ya Powell había emitido en su día la hipótesis de que se llamaba a la fiesta de este modo porque en ella se producía el "juntar unos rebaños con otros", así como la reunión de los distintos pueblos en asamblea. ${ }^{44}$ En distinto nivel se sitúa J. de Vries cuando rechaza la sugerencia de Powell -alegando que la idea es demasiado simple, porque al comenzar noviembre la estación de los pastos ya ha llegado a su fin (¿impide eso acaso reunir los ganados?)- y prefiere desarrollar una teoría que establece la celebración en esa fecha de un hierós gámos entre Dagda, dios terreno, y la diosa de los infiernos Morrígan; el nombre de Samain expresaría el recuerdo de aquella unión divina para simbolizar, como ceremonia agrícola, la demanda de la fertilidad; Samain sería el momento en que se reúnen ambos mundos (vivos y muertos), en el que potencias misteriosas venían a mezclarse con el mundo de los humanos. ${ }^{45}$ Pero su teoría no nos sirve para justificar a qué se debió aquel nombre de cét-samain dado a la celebración del 1 de mayo, que difícilmente alude a una primera unión, o unión en el equinoccio opuesto, de ambas divinidades, sino más bien a una asamblea previa, seis meses antes, a la denominada asamblea (Samain) por antonomasia. Siguiendo ahora la pista de las raíces celtibéricas de esta construcción jurisdiccional del ligallo nos vemos inclinados a considerar si no pudo ocurrir que el aparato formado en torno a la asamblea política y judicial, donde ciertamente se reunieron las jefaturas para celebrar ceremonias religiosas y presidir las competiciones, culminase con el cylch, el agrupamiento del ganado y la actuación del tribunal, el cual reordenaba la cuantificación federal del patrimonio pecuario, que repercutía en la atribución de una posición y un rango a los grupos familiares. Tal vez esa parte del festival fuera sentida por sus protagonistas en forma tan intensa, que resolvieron escoger como marca identificativa la voz que definía la suma de agrupaciones, es decir, la concentración o junta (samuhin) de elementos humanos (asamblea de la comunidad) y materiales (ganado).

Sea cual fuere la causa que condujo a estabilizar una forma onomástica como fue la de samuhin, resulta evidente que cuando en época romana el latín se impuso sobre las lenguas indígenas y hubo necesidad de referirse a este tribunal ganadero se procedió mediante el calco, tomando la raíz lig- por coincidir en su significado con el nombre céltico (junta, asamblea o agrupación) dado a la ocasión en que se realizaba la audiencia. No es más que un típico fenómeno de singlosia y absorción que afecta

${ }^{43}$ Como determinó J. Vendryés, "La religión des celtes", en A. Grenier, J. Vendryès, E. Tonnelat, B.-O. Unbegaun, I. Les religions étrusque et romaine. II. Les religions des Celtes, des Germains et des anciens Slaves («Mana». Introduction à l'Histoire des Religions - 2. Les religions de l'Europe ancienne, III), Paris 1948, p. 313.

${ }_{44}$ T. G. E. Powell, The Celts (Ancient Peoples and Places, 6), London 1958, p. 117.

45 J. DE VRIES, La religion des celtes, Paris 1977, pp. 237 s. 
a las lenguas de substrato, convincentemente destacado con ejemplos del ibérico y del indoeuropeo, en este mismo territorio que nos ocupa, por X. Ballester, de quien tomo la siguiente cita de Alinei: "la linguistica storica dovrà abituarsi all'idea che il fenómeno lingüístico è molto più antico di quanto si sia pensato finora, e che i nostri dialetti sono molto più le vestigia di sviluppi preistorici che non medievali". ${ }^{46}$ Por este conducto vemos con sorpresa, en definitiva, que el sentido exacto de samuhin ha podido permanecer presente e inalterado debajo del título del apelativo ligallo.

Debo terminar con varias reflexiones. En lo que respecta a la época medieval y siglos posteriores, cabe apuntar que a partir de los más antiguos y primeros ligallos de matriz celtibérica (XIII-XIV), reconocidos por los reyes de Aragón, la institución acabó extendiéndose por los territorios del antiguo reino aragonés, a solicitud de otras agrupaciones de ganaderos, dando lugar a formas particulares y extensiones del ligallo que no son ya de nuestra incumbencia. ${ }^{47}$ En segundo lugar, el hecho de que el viejo tribunal celtibérico hubiera sobrevivido a la ocupación romana serviría nuevamente para sustentar una idea firme y consolidada en la investigación, a saber, que Roma respetó en numerosas provincias los derechos locales, sin crear innecesarias interferencias en la correspondiente jurisdicción indígena. Pero además, en lo que hace a la historia antigua de la Península Ibérica la existencia de este tribunal del ganado, tal como la hemos reconstruido, vendría a reforzar fundadas sospechas sobre las raíces celtibéricas de la estructura de algunos territorios y su explotación ganadera, a proporcionar resultados de interés para otras parcelas históricas y a plantear algunas incógnitas, sobre las que en un futuro quizá quepa hacer más luz.

En efecto, la pervivencia de esta institución jurídica vuelve a poner de manifiesto que los territorios comprendidos en el área oriental y meridional de la provincia de Teruel, así como las zonas limítrofes con Cuenca, mantuvieron casi intactas las improntas celtibéricas y sus elementos demográficos y económicos agropecuarios, como certeramente propuso M. Almagro Gorbea analizando las mancomunidades de Teruel y de Albarracín. ${ }^{48}$ Revestiría gran interés el conseguir profundizar en el origen

${ }^{46}$ X. BALlester, "Del latín [ibérico] al romance [catalán]", en Del llatí al romanç, com hem emplenat el buit? III Jornada de l'Associació d'amics del professor Antoni M. Badia i Margarit (Barcelona, 17 de maig de 2007) [Institut d'Estudis Catalans. Biblioteca Filològica, LXIV), Barcelona 2008, pp. 87 s..

${ }^{47}$ Este proceso puede seguirse a partir de los estudios de M. Mitián, "Notas para la historia del lligalló de Morella", Boletín de la Sociedad Castellonense de Cultura 8, 1927, pp. 179-185; RABASSA, loc. cit., pp. 81-98; J. A. Fernández Otal, La Casa de ganaderos de Zaragoza. Derecho y trashumancia a fines del siglo XV, Zaragoza 1993, pp. 68-70; IDEM, Documentación medieval de la Corte del Justicia de Ganaderos de Zaragoza (Fuentes históricas aragonesas, 21), Zaragoza 1995, pp. 141-159; IDEM, loc. cit., pp. 65-73 y 118 s. (con el resto de la bibliografía sobre el ligallo); J. L. CASTÁn EsteBAn, Pastores turolenses. Historia de la trashumancia aragonesa en el Reino de Valencia durante la época foral moderna, Zaragoza 2002, pp. 167-176; J. M. Berges, "Para una historia de las instituciones pastoriles en Aragón: la Mesta de Albarracín a través de sus ordinaciones", en J. L. Castán Esteban y C. Serrano Lacarra (eds.), La trashumancia en la España mediterránea. Historia, Antropología, Medio Natural, Desarrollo Rural, Zaragoza 2004, pp. 265-271.

${ }^{48}$ M. Almagro Gorbea, “Aproximación paleoetnológica a la Celtiberia meridional: las serranías de Albarracín y Cuenca”, en Poblamiento celtibérico, II (III Simposio sobre los celtíberos), Zaragoza 1995, 433-446; IdEM, "La Serranía de Albarracín. Análisis etno-arqueológico de la ganadería en la Celtiberia meridional", en Los rebaños de Gerión. Pastores y trashumancia en Iberia antigua y medieval. Seminario celebrado en la Casa de Velázquez (15-16 de enero de 1996). Actas reunidas y presentadas por 
verdadero de la división en sexmas de la ciudad de Teruel después de conquistada, pues es asunto rodeado de cierto misterio ${ }^{49}$; nada habría de extraño en que estas circunscripciones fueran reflejo, junto con Teruel, de una vieja y poderosa federación de siete miembros, con todos los caracteres propios (fiestas, dehesa/santuario, ordalías, tribunal del ganado). Tampoco debe sorprender que salga indiscutiblemente a la luz el linaje celtibérico de las tierras situadas, en la provincia de Castellón, desde el Alto Maestrazgo (Chert, Cálig, Rosell, La Jana, Canet, Traiguera, San Mateo, Culla) hasta las montañas (puertos) de Morella y sus comunidades anejas. Ya señalé en otro lugar que el santuario rupestre (y el nombre) de la Balma, cercano a Morella, era un representante directo del mundo céltico; y es además probable que la capital de la vieja federación morellana fuese la ciudad de Lassira o Lessira (ubicada seguramente junto a Forcall, en La Moleta des Frares).$^{50}$ Esta ciudad se halla citada en la Geografía de Ptolomeo (II, 6, 62), y acerca de su nombre caben fundadas razones para suponer que es indoeuropeo y probablemente céltico.$^{51}$ Los miembros de esta federación podrían ser adscritos, creo, a la vieja rama de los beribraces (bebrices), mencionados en el periplo de Avieno (Or. Mar. 485-489) como dedicados plenamente a la ganadería (y por eso aquí se habría mantenido inconcuso el ligallo). ${ }^{52}$

Nuestro planteamiento afecta asimismo, por último, al campo religioso festivo y de las asambleas oficiales, puesto que pone al descubierto la gran importancia de la fiesta de Samain (1 de noviembre) también en la Península Ibérica con un testimonio de enorme peso, y viene a confirmar que sobre ambas festividades, Beltene y Samain, giró sin duda la vida pública de los celtíberos. Lamentablemente, una imagen histórica que nos resulta imposible obtener es cómo se resolvían los problemas de apropiación y reclamaciones de ganado entre dos distintas federaciones celtibéricas. ¿Estaban previstas mediante pactos concretos las indemnizaciones, las devoluciones, los intercambios? ¿Se utilizaron con este objeto algunas téseras especiales, que certificaban contraseñas relativas a los ganados? ¿Hubo pastizales compartidos? ¿Eran frecuentes las correrías en busca de ganado? ¿Qué consecuencias causaban? Las respuestas no son fáciles. Mas parece verosímil suponer que la vecindad entre federaciones, la política de hostilidad hacia los extraños y el difícil equilibrio fronterizo tuvo que ser fuente, en bastantes ocasiones, de roces y refriegas. Si tenemos en cuenta cómo se actuó en otros territorios del mundo indoeuropeo cuyos habitantes y autoridades vivían circunstancias análogas, por ejemplo en Creta, cabe imaginar que también en la Península Ibérica debieron establecerse numerosos tratados y acuerdos, tanto para

Joaquín Gómez-Pantoja (Collection de la Casa de Velázquez. Volumen nº 73), Madrid 2001, 233-262; IDEM, "Aproximaciones a la demografía de la Celtiberia", en L. Berrocal-Rangel y Ph. Gardes (eds.), Entre celtas e íberos. Las poblaciones protohistóricas de las Galias e Hispania (Bibliotheca Archaeologica Hispana 8), Madrid 2001, 45-60.

${ }^{49}$ Como ya advirtió A. Gargallo Moya, Los orígenes de la Comunidad de Teruel, Teruel 1984.

${ }^{50}$ G. AlföLdY, Res publica leserensis (Forcall, Castellón) [Trabajos varios del SIP, 55], Valencia 1977.

51 Vid. J. L. García Alonso, La Península Ibérica en la Geografía de Claudio Ptolomeo, Vitoria 2003, p. 374.

52 Sobre este grupo étnico indoeuropeo puede verse F. J. Fernández Nieto, "Beribraces, edetanos e ilercaones (pueblos prerromanos en la actual provincia de Castellón)", Zephyrus 19-20, 1968-1969, pp. 129-134. 
permitir al tránsito de ganado como, sobre todo, para evitar el menoscabo de la cabaña. ${ }^{53}$ Muy elocuente es el relato que figura en las Helénicas de Oxirrinco (XV, 3 B.) sobre los antecedentes de la sublevación de Grecia Central contra Esparta, en el 395 a.C.: "existía un territorio en los alrededores del Parnaso que era objeto de disputa entre ambos pueblos (locrios y focidios); ya en otras épocas se habían enfrentado por la propiedad del mismo. Cada uno de ellos lo explotaba a menudo para pastos, y cuando sabían que sus contrarios habían reunido allí los ganados, se los arrebataban en una razia. Todas estas disputas siempre las resolvían en común mediante la justicia y el diálogo, pero en aquella ocasión, en que los locrios reaccionaron tomándoles el ganado a cuenta del que los focidios les habían robado, los focidios, excitados por grupos propios patrocinados por Androclides e Ismenias ${ }^{54}$, reaccionaron invadiendo armados la Lócride". En mi opinión, también en la Celtiberia debió tenderse a resolver los enfrentamientos por los pastos y el ganado mediante el diálogo y la justicia, aunque en el curso de su historia nunca faltaran las guerras y luchas entre distintas federaciones ni los disturbios de raíz económica dentro de una misma etnia.

${ }^{53}$ De la especial situación de las poleis en Creta, asentadas en pequeños territorios y rodeadas de vecinos más o menos hostiles, y de la forma en que establecieron numerosos acuerdos para sacar adelante sus rebaños, se ha ocupado A. CHANIOTIS, "Problems of "Pastoralism" and "Transhumance" in Classical and Hellenistic Crete", Orbis Terrarum 1, 1995, pp. 39-89; IDEM, Die Verträge zwischen kretischen Poleis in der hellenistischen Zeit, Stuttgart 1996, pp. 114-120.

54 Se trataba de dos agentes tebanos, interesados en que estallase el conflicto. Véase cómo en este asunto hay un tercer Estado (Tebas) que utiliza las viejas heridas de ambos contendientes, locrios y focidios, dolidos por las pérdidas de ganado, para que se inicie un ataque armado del que los tebanos esperaban obtener beneficios. 